\title{
Strains of Blue Grama and Sideoats Grama Evaluated for the Southern Great Plains
}

\author{
WILliaM D. PITMAN AND CHESTER C. JAYNES
}

\begin{abstract}
Strains of blue grama and sideoats grama were evaluated for forage yield and quality under dryland conditions on the Southern Great Plains. In vitro dry matter digestibility (IVDMD) and crude protein content were determined as measures of forage quality. WW 65 blue grama was the leading strain of blue grama for every parameter measured, but it was significantly greater than the other blue grama strains only in IVDMD. Although no strain of sideoats grama proved superior in forage yield, PMT 328 sideoats grama was highest in crude protein content and was significantly greater than all other strains of sideoats grama in IVDMD. WW 65 blue grama and PMT 328 sideoats grama exhibited superior forage quality with at least comparable forage yield to the other strains of blue grama and sideoats grama, respectively.

Underground irrigation water in a large portion of the Southern Great Plains is now declining. Many soils in this area are highly susceptible to wind erosion when' intensively cultivated under dryland conditions. Re-establishment of permanent vegetation is an obvious alternative for these

\footnotetext{
Authors are former graduate research assistant and associate professor emeritus, respectively, Texas Tech University and Texas Agricultural Experiment Station, Lubbock, Texas. Presently the senior author is a graduate research assistant of Texas

This investigation was supported by the Cooperative Research Program of the

Manuscript received May 14, 1979.
} A\&M University, College Station. Texas Agricultural Experiment Station and Texas Tech University. This article is TA 14922 from the Texas Agricultural Experiment Station. The authors wish to thank the Southern Great Plains Field Station, Woodward, Oklahoma, and the SCS Plant Materials Center, Knox City, Texas, for supplying certain entries used in the nursery
study.
\end{abstract}

areas. Plants with drought resistance and grazing tolerance are essential for utilization by livestock in this region of periodic drought and other environmental extremes.

Blue grama, Bouteloua gracilis (H.B.K.) Lag. ex. Steud., and sideoats grama, Bouteloua curtipendula (Michx.) Torr., are recognized as important grasses for revegetating erodible areas of the Great Plains (Hoover et al. 1947; Mcllvain and Shoop 1960). Potential production of these species under irrigation and fertilization was determined on the High Plains of Texas (Jaynes and Hunter 1961; Lehman et al. 1969). Holscher (1945), Newell et al. (1962), Dwyer (1971), and Willard and Schuster (1971) reported on the performance of certain strains of blue grama and sideoats grama grown under dryland conditions. Animal performance was evaluated from grazing studies with these grasses on the Southern Great Plains at Woodward, Okla., (McIlvain and Shoop 1960) and at Amarillo, Texas (Whitfield et al. 1949). These studies indicate that forage production of blue grama and sideoats grama was generally comparable to that of other adapted species in favorable years with greater tolerance to grazing in less favorable years. Several improved strains of these species have been developed and are now available.

This study was conducted to evaluate currently available selections and experimental strains of blue grama and side- 
oats grama for dryland production in the Southern Great Plains. Forage yicld and forage quality were determined on the strains evaluated.

\section{Materials and Methods}

The field study was on an established plant materials nursery at the Texas Agricultural Experiment Station north of Lubbock, Texas. The grasses were seeded in 1973. Four strains of blue grama and eight strains of sideoats grama were replicated three times in a randomized complete block design.

Grasses evaluated included commercially available and experimental strains (Table 1). Strains of blue grama used were common blue grama and the experimental selections PMT 697, PMT 1221, and WW 65. Strains of sideoats grama were as follows: Premier, El Reno, Vaughan, Uvalde, and the experimental selections Block E, PMT 470, PMT 201, and PMT 328. Each entry occupied a $3 \times 4 \mathrm{~m}$ plot. Plantings were in rows with each plot being four rows wide.

Herbage yields were determined by clipping during the 1976 and 1977 growing seasons. A section $60 \mathrm{~cm}$ long in each of the two inside rows in each plot was clipped. Forage from the two rows was composited into one sample per replication. Both species were harvested on the same dates throughout the growing season. Harvests were made immediately after all plots of blue grama had attained a minimum height of $15 \mathrm{~cm}$ and all plots of sideoats grama had attained a minimum of $20 \mathrm{~cm}$. Blue grama was clipped at a 7.5 $\mathrm{cm}$ stubble height while sideoats grama was clipped at a $10 \mathrm{~cm}$ stubble height. The material was dried at $50^{\circ} \mathrm{C}$ for 72 hours then weighed. Samples taken in 1976 were then ground to pass through a $0.5 \mathrm{~mm}$ screen in preparation for further analysis.

In vitro dry matter digestibility (IVDMD) and crude protein determinations were used as measures of quality of the total available forage. These analyses were made on the plant material harvested during the 1976 growing season. The IVDMD procedure used was the Tilley and Terry (1963) two-stage method with modifications as described by Teel (1970). Protein determinations were made by the Kjeldahl procedure (Association of Official Agricultural Chemists 1965).

Forage yicld, pcrcent IVDMD, and percent crude protein were statistically analyzed, and the parameters with significant differences among selections were compared using Duncan's multiple range test.

\section{Results and Discussion}

The frequent harvests in 1976 made it possible to deter-
Table 2. In vitro dry matter digestibility, crude protein, and yield of blue grama strains on the Southern High Plains.

\begin{tabular}{lcccc}
\hline \hline & $\begin{array}{c}\text { Weighted } \\
\text { mean }^{1} \\
\text { IVDMD } \\
(1976)\end{array}$ & $\begin{array}{c}\text { Weighted } \\
\text { mean crude } \\
\text { protein } \\
(1976)\end{array}$ & $\begin{array}{c}\text { Yield } \\
(1976)\end{array}$ & $\begin{array}{c}\text { Yield } \\
(1977)\end{array}$ \\
Strain & $\%$ & $\%$ & $\mathrm{~kg} / \mathrm{ha}$ & $\mathrm{kg} / \mathrm{ha}$ \\
& $61.54 \mathrm{a}^{3}$ & $16.68 \mathrm{a}$ & $2752 \mathrm{a}$ & $2254 \mathrm{a}$ \\
WW 65 & $60.06 \mathrm{~b}$ & $15.24 \mathrm{a}$ & $2463 \mathrm{a}$ & $2094 \mathrm{a}$ \\
PMT 1221 & $59.63 \mathrm{~b}$ & $16.09 \mathrm{a}$ & $2226 \mathrm{a}$ & $1689 \mathrm{a}$ \\
Common & $59.03 \mathrm{~b}$ & $16.12 \mathrm{a}$ & $2668 \mathrm{a}$ & $1701 \mathrm{a}$ \\
PMT 697 & &
\end{tabular}

'Weighted means were calculated by multiplying the percent IVDMD and crude protein, respectively, of each harvest by the yield for that harvest, totaling the products, and dividing this total by the total yield for the year.

${ }^{2}$ Total yield from harvests on May 11, June 3, June 27, Aug. 8, Sept. 12, and Oct. 21. ${ }^{3}$ Means within each column followed by the same letter are not significantly different at the .05 level.

mine the quality of forage available throughout the growing season as environmental conditions changed. Higher stubble heights than usual were maintained to compensate for the effects of frequent clipping on plant vigor. Forage harvested in this study was undoubtedly affected by the interaction of clipping frequency and stubble height. As shown by Holscher (1945) and Crowston and Goetz (1976), higher yields would be expected with less frequent clipping.

\section{Blue Grama}

Significant yield differences among the blue grama selections were obtained on only six of the 16 harvest dates during the two years of this study. Differences in precipitation patterns between the two seasons did not greatly affect the comparative forage yields of the four selections. WW 65 produced the most forage during both years, but this was not significantly greater than any of the other selections (Table 2).

Forage quality, as measured by IVDMD, indicated WW 65 to be significantly more digestible than the other selections for the total growing season (Table 2). Significant differences were also obtained for several of the individual harvest dates during the growing season (Table 3). WW 65 also had higher crude protein, although it was not signifi-

Table 1. Description of experimental blue grama and sideoats grama strains.

\begin{tabular}{|c|c|c|c|}
\hline Strain & Origin and/or strain development & Source of strain & Growth form ${ }^{\prime}$ \\
\hline \multicolumn{4}{|l|}{ Blue grama } \\
\hline PMT 697 & $\begin{array}{l}\text { Selection of material originally collected at Asper- } \\
\text { mont, Texas }\end{array}$ & SCS Plant Materials Center, Knox City, Texas & \\
\hline PMT 1221 & $\begin{array}{l}\text { Composite of materials collected on alkaline soils } \\
\text { in Oklahoma }\end{array}$ & SCS Plant Materials Center, Knox City, Texas & \\
\hline WW 65 & $\begin{array}{l}\text { Developed through recurrent selection of materials } \\
\text { primarily from Texas and New Mexico }\end{array}$ & $\begin{array}{l}\text { Southern Great Plains Field Station, Woodward, } \\
\text { Oklahoma }\end{array}$ & \\
\hline \multicolumn{4}{|l|}{ Sideoats grama } \\
\hline Block E & $\begin{array}{l}\text { Developed through recurrent selection of materials } \\
\text { primarily from Oklahoma and Texas }\end{array}$ & $\begin{array}{l}\text { Southern Great Plains Field Station, Woodward, } \\
\text { Oklahoma }\end{array}$ & Rhizomatous \\
\hline PMT 201 & $\begin{array}{l}\text { Selection of material originally collected at Throck- } \\
\text { morton, Texas }\end{array}$ & SCS Plant Materials Center, Knox City, Texas & Slightly rhizomatous \\
\hline PMT 328 & $\begin{array}{l}\text { Selection of material originally collected at Van } \\
\text { Horn, Texas }\end{array}$ & SCS Plant Materials Center, Knox City, Texas & Bunchgrass \\
\hline PMT 470 & $\begin{array}{l}\text { Selection of material originally collected in Haskell } \\
\text { County, Texas }\end{array}$ & SCS Plant Materials Center, Knox City, Texas & Rhizomatous \\
\hline
\end{tabular}

'For sideoats grama only. 
Table 3. In vitro dry matter digestibility of four blue grama strains clipped throughout the growing season in 1976.

\begin{tabular}{|c|c|c|c|c|}
\hline \multirow[b]{2}{*}{ Clipping date } & \multicolumn{4}{|c|}{ Blue grama strain } \\
\hline & Common & PMT 697 & PMT 1221 & WW 65 \\
\hline & $\%$ & $\%$ & $\%$ & $\%$ \\
\hline May 28 & $60.71 b^{1}$ & $65.77 \mathrm{a}$ & $66.47 \mathrm{a}$ & $64.72 \mathrm{a}$ \\
\hline June 15 & $54.48 \mathrm{ab}$ & $52.63 \mathrm{~b}$ & $55.70 \mathrm{ab}$ & $57.67 \mathrm{a}$ \\
\hline July 9 & $65.82 \mathrm{a}$ & $61.71 \mathrm{a}$ & $62.43 \mathrm{a}$ & $63.55 \mathrm{a}$ \\
\hline July 20 & $62.68 \mathrm{a}$ & $61.36 \mathrm{a}$ & $62.13 \mathrm{a}$ & $63.20 \mathrm{a}$ \\
\hline July 30 & $56.78 \mathrm{~b}$ & $58.12 \mathrm{~b}$ & $57.28 \mathrm{~b}$ & $60.27 \mathrm{a}$ \\
\hline Aug. 9 & $62.18 \mathrm{a}$ & $60.56 \mathrm{a}$ & $62.59 \mathrm{a}$ & $62.57 \mathrm{a}$ \\
\hline Aug. 20 & $57.66 \mathrm{~b}$ & $57.07 \mathrm{~b}$ & $59.28 \mathrm{a}$ & $59.44 \mathrm{a}$ \\
\hline Sept. 2 & $55.32 \mathrm{~b}$ & $53.76 \mathrm{c}$ & $54.72 \mathrm{bc}$ & $47.04 \mathrm{a}$ \\
\hline Sept. 18 & $55.15 \mathrm{~b}$ & $57.58 \mathrm{ab}$ & $60.17 \mathrm{a}$ & $59.27 \mathrm{a}$ \\
\hline Oct. 2 & $49.86 \mathrm{c}$ & $53.42 \mathrm{a}$ & $52.00 \mathrm{ab}$ & $51.54 \mathrm{~b}$ \\
\hline
\end{tabular}

'Means within each row followed by the same letter are not significantly different at the .05 level.

cantly greater than the other selections (Table 2).

\section{Sideoats Grama}

Total yields of the eight sideoats grama strains did not differ significantly in 1976 (Table 4). The first 2 months of the growing season were extremely dry. During this time, PMT 328 and Premier produced significantly more forage than the other strains except Uvalde and El Reno (Table 5). Uvalde and El Reno did not produce significantly more than any other strain for this period.

After the first harvest in July, moisture conditions were much more favorable for plant growth. All sideoats grama

Table 4. In vitro dry matter digestibility, crude protein, and yield of sideoats grama strains on the Southern High Plains.

\begin{tabular}{|c|c|c|c|c|}
\hline Strain & $\begin{array}{l}\text { Weighted } \\
\text { mean }^{1} \\
\text { IVDMD } \\
(1976) \\
\end{array}$ & $\begin{array}{c}\text { Weighted } \\
\text { mean } \\
\text { Crude } \\
\text { Protein } \\
(1976) \\
\end{array}$ & $\begin{array}{l}\text { Yield } \\
(1976) \\
\end{array}$ & $\begin{array}{l}\text { Yield }^{2} \\
(1977)\end{array}$ \\
\hline & $\%$ & $\%$ & $\mathrm{~kg} / \mathrm{ha}$ & $\mathrm{k} / \mathrm{ha}$ \\
\hline PMT 328 & $58.59 \mathrm{a}^{3}$ & $17.09 \mathrm{a}$ & $3717 a$ & $3503 \mathrm{ab}$ \\
\hline Premier & $57.16 \mathrm{~b}$ & $16.42 \mathrm{ab}$ & 3903 a & $4185 \mathrm{a}$ \\
\hline El Reno & $57.05 \quad b$ & $15.85 \mathrm{ab}$ & 3387 a & 3041 abc \\
\hline Uvalde & $56.62 \mathrm{bc}$ & $16.01 \mathrm{ab}$ & $4132 \mathrm{a}$ & 2275 bcd \\
\hline Vaughan & $55.93 \mathrm{~cd}$ & $15.15 \mathrm{ab}$ & $3267 \mathrm{a}$ & 2270 bcd \\
\hline PMT 470 & 55.02 & $15.00 \mathrm{ab}$ & $3135 \mathrm{a}$ & $1926 \mathrm{~cd}$ \\
\hline Block E & 54.51 & $14.35 \mathrm{~b}$ & $3510 \mathrm{a}$ & 2519 bcd \\
\hline РМТ 201 & 54.22 & $14.09 \mathrm{~b}$ & 3357 a & $1475 \mathrm{a}$ \\
\hline
\end{tabular}

IWeighted means were calculated by multiplying the percent IVDMD and crude protein, respectively, of each harvest by the yield for that harvest, totaling the products, and dividing this total by the total yield for the year.

${ }^{2}$ Total yield from harvests on May 11, June 3, June 27, Aug. 8, Sept. 12, and Oct. 21. ${ }^{3}$ Means within each column followed by the same letter are not significantly different at the .05 level. strains produced more than during the previous dry period, and they all responded similarly to the increased moisture for the remainder of the growing season.

Forage yields were significantly different for the sideoats grama strains during the 1977 growing season (Table 4). Differences in forage production for 1977 were similar to those obtained during the dry portion of the 1976 growing season (Table 5). Rainfall during the 1977 growing season was $25 \mathrm{~cm}$, and it was distributed more uniformly throughout the growing season than the $40 \mathrm{~cm}$ received during the 1976 season.

PMT 328 was significantly higher in IVDMD than the other strains (Table 4). Premier and El Reno had a greater IVDMD than any of the remaining selections except

Table 5. Yield of eight sideoats grama strains as influenced by rainfall on the Southern High Plains in 1976.

\begin{tabular}{lcc}
\hline \hline Strain & May $1-$ July $9^{1}$ & July $9-$ Oct. $9^{2}$ \\
\hline & $\mathrm{kg} / \mathrm{ha}$ & $\mathrm{kg} / \mathrm{ha}$ \\
PMT 328 & $1146 \mathrm{a}^{3}$ & $2571 \mathrm{a}$ \\
Premier & $1097 \mathrm{a}$ & $2806 \mathrm{a}$ \\
Uvalde & $814 \mathrm{ab}$ & $3318 \mathrm{a}$ \\
El Reno & $672 \mathrm{ab}$ & $2715 \mathrm{a}$ \\
PMT 201 & $627 \mathrm{~b}$ & $2730 \mathrm{a}$ \\
Block E & $570 \mathrm{~b}$ & $2940 \mathrm{a}$ \\
Vaughan & $537 \mathrm{~b}$ & $2730 \mathrm{a}$ \\
PMT 470 & $310 \mathrm{~b}$ & $2825 \mathrm{a}$ \\
\hline
\end{tabular}

'During this portion of the growing season moisture was limited with $11.77 \mathrm{~cm}$ of rainfall following a dry winter.

2During this portion of the growing season $28.33 \mathrm{~cm}$ of rainfall was received resulting in adequate moisture for growth.

${ }^{3}$ Means within each column followed by the same letter are not significantly different at the .05 level.

Table 6. In vitro dry matter digestibility of eight sideoats grama strains clipped throughout the growing season in 1976.

\begin{tabular}{|c|c|c|c|c|c|c|c|c|}
\hline \multirow[b]{2}{*}{ Clipping date } & \multicolumn{8}{|c|}{ Sideoats grama strain } \\
\hline & Premier & El Reno & Vaughan & Uvalde & Block E & PMT 470 & PMT 201 & PMT 328 \\
\hline & $\%$ & $\%$ & $\%$ & $\%$ & $\%$ & $\%$ & $\%$ & $\%$ \\
\hline May 28 & 58.83 & 61.91 & 60.01 & 58.84 & $66.15 \mathrm{a}$ & $66.13 \mathrm{a}$ & $64.52 \mathrm{~b}$ & $67.26 \mathrm{a}$ \\
\hline June 15 & 54.22 bc & 53.79 bc & $52.18 \mathrm{c}$ & $51.94 \mathrm{c}$ & $56.02 \mathrm{ab}$ & $58.03 \mathrm{a}$ & $52.69 \mathrm{bc}$ & $55.11 \mathrm{abc}$ \\
\hline July 9 & $58.38 \mathrm{ab}$ & $59.67 \mathrm{a}$ & $58.59 \mathrm{ab}$ & $57.83 \mathrm{ab}$ & $55.28 \mathrm{c}$ & $56.39 \mathrm{bc}$ & $54.86 \mathrm{c}$ & $58.71 \mathrm{ab}$ \\
\hline July 20 & $58.37 \mathrm{~b}$ & $61.77 \mathrm{a}$ & $59.14 \mathrm{~b}$ & $60.20 \mathrm{ab}$ & $58.96 \mathrm{~b}$ & $58.69 \mathrm{~b}$ & $55.07 \mathrm{c}$ & $58.04 \mathrm{~b}$ \\
\hline July 30 & $57.66 \mathrm{a}$ & $54.92 \mathrm{~b}$ & $55.75 \mathrm{ab}$ & $54.53 \mathrm{~b}$ & $53.60 \mathrm{~b}$ & $54.55 \mathrm{~b}$ & $54.75 \mathrm{~b}$ & $58.00 \mathrm{a}$ \\
\hline Aug. 9 & $56.46 \mathrm{~b}$ & $59.43 \mathrm{a}$ & $60.52 \mathrm{a}$ & $60.31 \mathrm{a}$ & $54.77 \quad b$ & $56.36 \mathrm{~b}$ & $55.49 \mathrm{~b}$ & $58.80 \mathrm{a}$ \\
\hline Aug. 20 & $56.99 \mathrm{bc}$ & $55.59 \mathrm{~cd}$ & $55.36 \mathrm{~cd}$ & $58.36 \mathrm{ab}$ & 54.72 & 54.38 & 54.08 & $60.04 \mathrm{a}$ \\
\hline Sept. 2 & $55.76 \mathrm{a}$ & $50.05 \quad b$ & $49.65 \mathrm{bc}$ & $50.45 \mathrm{~b}$ & $48.94 \mathrm{bc}$ & $49.97 \mathrm{~b}$ & $47.96 \mathrm{c}$ & $57.44 \mathrm{a}$ \\
\hline Sept. 18 & $54.28 \mathrm{a}$ & $39.77 \quad d$ & $42.04 \mathrm{~cd}$ & $50.13 \mathrm{~b}$ & 40.35 & $44.50 \quad \mathrm{c}$ & $41.55 \mathrm{~cd}$ & $56.25 \mathrm{a}$ \\
\hline Oct. 9 & $48.68 \mathrm{ab}$ & $48.54 \mathrm{ab}$ & $46.94 \quad b$ & $48.71 \mathrm{ab}$ & $46.03 \mathrm{~b}$ & $45.69 \mathrm{~b}$ & $45.18 \mathrm{~b}$ & $51.60 \mathrm{a}$ \\
\hline
\end{tabular}

'Means within each row followed by the same letter are not significantly different at the .05 level. 
Uvalde. Table 6 shows the differences in IVDMD by harvest dates throughout the growing season. Significant differences in crude protein content existed only between the highest strain, PMT 328, and the lowest strains, Block E and PMT 201 (Table 4).

\section{Conclusion}

Under the conditions of this evaluation, WW 65 blue grama was superior to the other three strains in forage quality as indicated by IVDMD. Significant differences in yield did not occur among the strains, although WW 65 was consistently the leading producer.

Production of the eight sideoats grama strains was similar when moisture stress was not a factor. During periods of limited moisture, Premier and PMT 328 produced the highest forage yields. PMT 328 sideoats grama was more digestible than the other strains. Premier, El Reno, and Uvalde were also high in forage quality.

From this study, no single strain of either species can be recommended for use on the basis of superior forage yield. However, WW 65 blue grama and PMT 328 sideoats grama were superior in forage quality with at least comparable forage yield under the conditions of this evaluation. WW 65 blue grama and PMT 328 sideoats grama have potential to

\section{THE FOOD AND AGRICULTURE ORGANIZATION OF THE UNITED NATIONS, ROME, ITALY}

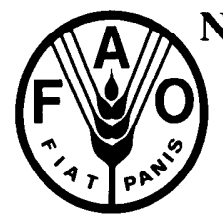

has openings for

\section{Range Management Research Scientist Range Ecologist Fodder Crops Expert Range Management Expert Pasture Ecologist}

for two and three-year postings to Misurata and Tripoli, Libya, to work in three important projects operated jointly by Libya and FAO, directed to maintain and improve Libya's pasture lands and maximize its potential off-take. Main objectives: investigation and research on national exploitation and management; preparation of management models for various ecological zones; developing fodder crop production and establishing forage reserves; establishing pasture units that integrate pastures, fodder crops and animal husbandry activities, taking into account social and legislative aspects.

$S A L A R Y$ : liberal according to professional experience and job contents, net tax-free with the large fringe benefits of the UN system. Please send detailed curriculum vitae quoting "UTFN/LIB" to FAO, Manpower Planning Unit, Agricultural Operations Division 00100 Rome, Itah (candidates from North America contact FAO Liaison Office, 1776 F Street, N.W., Washington, D.C. 20437 , USA). produce high quality forage on areas of the Southern Great Plains which need revegetation.

\section{Literature Cited}

Association of Official Agricultural Chemists. 1965. Official methods of analysis (10th Ed.). Ass. Offic. Agr. Chem., Washington, D.C.

Crowston, W.A. and H. Goetz. 1976. Fertilizer and clipping effects on ecotypes of western wheatgrass and blue grama. N.D. Agr. Exp. Sta. Bull. No. 502.70 p.

Dwyer, Don D. 1971. Nitrogen fertilization of blue grama range. New Mex. State Univ. Agr. Exp. Sta. Bull. 585.

Holscher, C.E. 1945. The effects of clipping bluestem wheatgrass and blue grama at different heights and frequencies. Ecology 26: 148-156.

Hoover, M.M., J.E. Smith, A.E. Ferber, and D.R. Cornelius. 1947. Seed for regrassing Great Plains areas. U.S. Dep. Agr. Farmers Bull. No. 1985. $37 \mathrm{p}$

Jaynes, Chester C., and John R. Hunter. 1961. Improved grasses for West Texas. Reports on Agricultural Industry. Texas Technological College. Vol. 2, No. 2. 2 p.

Lehman, O.R., J.J. Bond, and H.V. Eck. 1969. Forage potential of irrigated blue grama with nitrogen fertilization. J. Range Manage. 21: 71-73.

McIlvain, E.H. and M.C. Shoop. 1960. An agronomic evaluation of regrassing cropland in the Southern Great Plains. Workshop on Regrassing Cropland. ARS. USDA (Mimeo) $6 \mathrm{p}$.

Newll, L.C., R.D. Staten, E.B. Jackson, and E.C. Conrad. 1962. Sideoats grama in the Central Great Plains. Nebr. Exp. Sta. Res. Bull. 207. 38 p.

Teel, D.W. 1970. Inter- and intra-specific variations in the in vitro digestible dry-matter of four warm-season grasses. MS Thesis. Univ. of Nebr. Lincoln.

Tilley, J.M.A., and R.A. Terry. 1963. A two stage technique for the in vitro digestion of forage crops. J. Brit. Grassl. Soc. 18: 104-111.

Whitfield, C.J., J.H. Jones, and J.P. Baker. 1949. Grazing studies on the Amarillo Conservation Experiment Station. Tex. Agr. Exp. Sta. Bull. No. 717.22 p.

Willard, E. Earl, and Joseph L. Schuster. 1971. An evaluation of an interseeded sideoats grama stand four years after establishment J. Range Manage. 24: 223-226.

\section{Price List for Publications}

Rangeland Entomology ...................... 2.75

Quotable Range Quotes.................... \$ .75

Proceedings: First International Rangeland

Congress.......................... \$72.00

Rangeland Reference Areas ................\$ 2.00

Glossary of Terms ...................... \$ 1.50

Jornada Experimental Range ...............\$2.50

Proceedings of U.S. Australia Workshops:

Arid Shrublands ..........................\$ 3.50

Rangeland Ecosystem Evaluation and

Management ........................\$8.00

Symposium on Resources for Beef Cattle

Production ...........................\$ 3.50

Rangeland Plant Physiology............... .\$14.50

Special Management Needs of Alpine Ecosystems.. \$ 4.50 